\title{
Pengaruh Modifikasi Permainan Tradisional Engklek Terhadap Perkembangan Motorik Kasar Anak Usia 5-6 Tahun
}

\author{
Hellen Lorena ${ }^{1)^{*}}$, Rizky Drupadi 1)*, Ulwan Syafrudin ${ }^{1{ }^{*}}$ \\ ${ }^{1}$ FKIP Universitas Lampung, Jl. Prof. Dr. Soemantri Brojonegoro No.1 \\ E-mail: hellenlorena213@gmail.com
}

\begin{abstract}
The Influence of Modification of Traditional Engklek Games on Gross Motor Development of 5-6 Years Old Children. Based on observations in 10 children aged 5-6, there are children who have gross motor development in the low category and in the moderate category. This suggests that there is a lack of understanding and stimulus for gross motor development. The purpose of this study was to determine whether there is an effect of modification of the traditional crank game on gross motor development in children aged 5-6. This research approach uses quantitative research with the type of research Quasi Experimental Methods with One group Pretest-Posttest. Collecting data in this study using observation and documentation aimed at children to strengthen data about the effect of modification of the traditional crank game on children's gross motor skills. From the data analysis, it is known that there is an increase in children's fine motor skills which can be seen from the pretest observations which get an average score of $28.50 \%$ in the Underprivileged (KM) category and posttest which get an average score of $51.30 \%$ in the Capable category( $M)$. The results showed that there was an effect of collage on gross motor development in children aged 5-6 years.
\end{abstract}

Keywords: engklek traditional games, gross motor development, early childhood.

\begin{abstract}
Abstrak. Pengaruh Modifikasi Permainan Tradisional Engklek Terhadap Perkembangan Motorik Kasar Anak Usia 5-6 Tahun. Berdasarkan pengamatan pada 10 anak berusia 5-6 terdapat anak yang memiliki perkembangan motorik kasar dengan kategori rendah dan dengan kategori sedang. Hal ini menunjukkan bahwa kurangnya pemahaman dan stimulus terhadap perkembangan motorik kasar. Tujuan penelitian ini untuk mengetahui adakah pengaruh modifikasi permainan tradisional engklek terhadap perkembangan motorik kasar pada anak usia 5-6. Pendekatan penelitian ini menggunakan penelitian kuantitatif dengan jenis penelitian Quasi Experimental Methods dengan One group Pretest-Posttest. Pengumpulan data pada penelitian ini menggunakan observasi dan dokumentasi yang ditujukan kepada anak untuk memperkuat data tentang pengaruh modifikasi permainan tradisional engklek terhadap kemampuan motorik kasar anak. Dari analisis data diketahui bahwa adanya peningkatan kemampuan motorik halus anak yang dapat dilihat dari observasi pretest yang memperoleh angka rata-rata 28,50\% masuk kategori Kurang Mampu (KM) dan posttest yang memperoleh angka rata-rata 51,30\% masuk kategori Mampu (M). Hasil penelitian menunjukkan bahwa terdapat adanya pengaruh kolase terhadap perkembangan motorik kasar pada anak usia 5-6 tahun.
\end{abstract}

Kata Kunci : permainan tradisional engklek, perkembangan motorik kasar, anak usia dini. 


\section{PENDAHULUAN}

Pendidikan merupakan salah satu usaha dalam menjawab permasalahan serta berbagai tantangan yang hadir dalam kehidupan sehari-hari. Di Indonesia pendidikan dimulai sejak dini yaitu pada jenjang pendidikan anak usia dini atau PAUD dan menurut Undangundang Republik Indonesia No 20 tahun 2003 Bab 1, pasal 1, butir 14, tentang Sistem Pendidikan Nasional, menyatakan bahwa pendidikan anak usia dini adalah suatu upaya pembinaan yang ditujukan kepada anak sejak lahir sampai dengan usia 6 tahun yang dilakukan melalui rangsangan pendidikan untuk membantu pertumbuhan dan perkembangan jasmani dan rohani agar anak memiliki kesiapan dalam memasuki pendidikan lebih lanjut.

Dalam penyelenggaraan pendidikan anak usia dini bertujuan untuk mengembangkan seluruh aspek perkembangan sesuai dengan tahapan usia anak agar dapat berkembang secara baik dan optimal. Salah satu aspek yang perlu dikembangkan yaitu perkembangan fisik motorik. Corbin dalam Sumantri (2005) mengemukakan bahwa perkembangan motorik adalah perubahan kemampuan gerak dari bayi sampai dewasa yang melibatkan berbagai aspek perilaku dan kemampuan gerak. Perkembangan fisik motorik sangat berpengaruh terhadap terhadap perilaku dan penguasaan keterampilan atau kemampuan bergerak anak dalam kehidupan sehari-hari. Aktivitas bergerak dapat dilakukan dengan bermain, karena bermain bagi anak usia dini merupakan suatu hal yang menyenangkan dan tidak dapat dipisahkan dalam kesehariannya. Menurut Hurlock (1987) bermain adalah proses di mana anak mencapai perkembangan yang utuh, baik fisik, intelektual, sosail, moral, dan emosional.

Kegiatan bermain dapat dilakukan dengan atau tanpa menggunakan alat permainan, alat permainan digunakan untuk menghasilkan sebuah pengertian atau memberikan informasi, memberikan kesenangan serta membangun dan mengembangkan imajinasi anak. Akhirakhir ini kegiatan bermain anak mengalami kemunduran khususnya terhadap permainan tradisional, permainan tradisional pada dasarnya merupakan permainan yang bersifat sederhana dan mengandalkan kekompakkan dari masing-masing peserta dalam kegiatan bermain. Permainan tradisional sangat erat dengan nilai etika, moral, dan budaya masyarakat pendukungnya. Menurut Iswinarti (2010) menyatakan bahwa permainan tradisional merupakan kekayaan budaya bangsa yang mempunyai nilai-nilai luhur untuk dapat diwariskan kepada anak-anak sebagai generasi penerus. Dapat disimpulkan bahwa permainan tradisional merupakan suatu permainan yang didapat dimainkan sendiri atau secara berkelompok yang merupakan peninggalan leluhur dan terus diwariskan secara turun-temurun.

Pemanfaatan

permainan tradisional sebagai media pembelajaran masih belum banyak digunakan dalam kegiatan pembelajaran pada anak usia dini. Anak-anak saat ini lebih senang ataupun menyukai permainan-permainan modern yang siap pakai, dengan demikian terdapat dampak buruk diantaranya yaitu anak mengalami keterlambatan perkembangan. Salah satunya keterlambatan pada perkembangan motorik anak, karena anak hanya terfokus pada bermain gawai dan anak kurang bergerak. Akibatnya anak akan mengalami keterlambatan pada motorik kasarnya salah satunya anak tidak dapat menjaga keseimbangannya ketika berjalan. Salah satu permainan tradisional yang dapat menstimulus perkembangan motorik anak khususnya motoric kasarnya yaitu permainan 
engklek. Menurut Askalin (2013) menyatakan bahwa permainan engklek adalah permainan tradisional yang masih banyak dimainkan oleh anak - anak masa kini. Permainan ini tidak terlalu membutuhkan tempat yang luas dalam pelaksanaannya, namun terdapat beberapa sekolah jarang menerapkan permainan outdor dengan alasan kondisi sekolah yang kecil ataupun sempit. Guru harus dapat memodifikasi permainan menjadi menarik, menyenangkan serta mudah digunakan dalam pembelajaran, khusunya untuk mengembangkan perkembangan motorik kasar anak. Berdasarkan permasalahan diatas yang ditemukan dalam hasil observasi maka penulis tertarik untuk melakukan penelitian dengan tujuan penelitian menganalisis pengaruh modifikasi permainan tradisional engklek terhadap perkembangan motorik kasar anak usia 56 tahun.

\section{METODE}

Metode merupakan salah satu faktor terpenting dalam sebuah penelitian, karena berhasil atau tidaknya sebuah penelitian sangat bergantung dengan metode yang digunakan oleh peneliti. Dalam penelitian ini menggunakan jenis penelitian kuantitatif dengan menggunakan metode Kuasi Eksperimen, penelitian Kuasi Eksperimen yaitu metode penelitian untuk mencari pengaruh perlakuan tertentu terhadap hasil lain dalam kondisi yang sama terkendalikan dengan ukuran sampel relatif kecil. Desain penelitian menggunakan Nonrandomized Control Group, Pretest-posstest design. Membandingkan dua kelompok yaitu kelompok kontrol dan kelompok eksperimen, dalam penelitian ini membandingkan hasil dari pre-test sebelum diberi perlakuan dan post-test sesudah diberi perlakuan. Penelitian ini akan tertuju untuk anak usia 5-6 tahun, dilaksakan dengan 6 kali pertemuan. Dengan pembagian 3 kali pertemuan sebelum diberi perlakuan dan 3 kali pertemuan sesuah diberi perlakuan. Guru dan peneliti mencatat peningkatan yang terjadi terhadap siswa dan membandingkan dengan hasil pencatatan sebelumnya. Kegiatan post test juga diberikan sebanyak 6 kali untuk mengetahui hasil dari perlakuan atau intervensi (Munir, 2019).

\section{HASIL DAN PEMBAHASAN}

Penelitian ini bertujuan untuk melihat pengaruh modifikasi permainan tradisional engklek terhadap perkembangan motorik kasar anak. Berdasarkan tujuan penelitian tersebut, maka hasil penelitan menunjukkan bahwa sebelum diberikan modifikasi permainan tradisional engklek terdapat 9 anak memiliki kemampuan motorik kasar berada pada kategori rendah dan 1 anak berada pada kategori sedang. Namun setelah anak diberikan modifikasi permainan tradisional engklek, hasil penelitian menunjukkan bahwa 10 anak semuanya memiliki kemampuan motorik kasar berada pada kategori tinggi dan tidak terdapat anak yang kemampuan motorik kasarnya berada pada kategori rendah lagi. Untuk lebih jelas tentang kemampuan motorik kasar anak sebelum dan setelah diberikan modifikasi permainan tradisional engklek dapat dilihat pada tabel dibawah ini:

Tabel 1. Perbandingan Skor PretestPosttest

\begin{tabular}{llcc}
\hline No. & $\begin{array}{c}\text { Nama } \\
\text { Inisial }\end{array}$ & $\begin{array}{c}\text { Skor } \\
\text { Pretest }\end{array}$ & $\begin{array}{c}\text { Skor } \\
\text { Posttest }\end{array}$ \\
\hline 1. & RPC & 27 & 57 \\
2. & DAS & 30 & 55 \\
3. & AK & 25 & 48 \\
4. & DF & 22 & 45 \\
5. & NP & 28 & 50 \\
6. & MGA & 35 & 52 \\
7. & NA & 29 & 47 \\
\hline
\end{tabular}




\begin{tabular}{llcc}
\hline No. & $\begin{array}{c}\text { Nama } \\
\text { Inisial }\end{array}$ & $\begin{array}{c}\text { Skor } \\
\text { Pretest }\end{array}$ & $\begin{array}{c}\text { Skor } \\
\text { Posttest }\end{array}$ \\
\hline 8. & APS & 32 & 54 \\
9. & FNS & 24 & 56 \\
10. & RA & 33 & 49 \\
\hline
\end{tabular}

Berdasarkan tabel 1, dapat disimpulkan bahwa terdapat perbedaan signifikan antara hasil pretest dan posttest. Hasil posttest menghasilkan skor lebih baik dibandingkan hasil pretest dan terjadi peningkatan yang cukup besar setelah diberikan modifikasi permainan tradisional engklek dibandingkan sebelum diberikan modifikasi permainan tradisional engklek. Kemampuan motorik kasar pada anak sebelum diberi perlakuan berada pada kategori rendah sebanyak 9 anak dan berada pada kategori sedang sebanyak 1 anak. Secara keseluruhan, hasil posttest menunjukkan peningkatan yang cukup besar.

Tabel 2. Rata-Rata Pretest dan Posttest

\begin{tabular}{cc}
\hline \multicolumn{2}{c}{ Rata-rata } \\
\hline Pretest & $28,50 \%$ \\
Posttest & $51,30 \%$ \\
\hline
\end{tabular}

Tabel 2 menunjukkan bahwa hasil observasi dari 17 anak terkait kemampuan motorik halus, rata-rata untuk pretest yaitu 28,50 persen dan ratarata untuk posttest yaitu 51,30 persen. Pada rata-rata hasil observasi mengalami peningkatan sebesar 22,80 persen. Hasil peningkatan pada tabel 2 ditunjukkan oleh adanya perubahan dari 9 anak kategori rendah dan 1 anak kategori sedang menjadi 10 anak yang semuanya berada pada kategori tinggi serta tidak adanya anak yang berada pada kategori rendah lagi dalam kemampuan motorik halusnya setelah diberikan perlakuan. Berdasarkan hasil tersebut, dapat disimpulkan bahwa pemberian modifikasi permainan tradisional engklek mampu meningkatkan kemampuan motorik kasar. Perubahan kemampuan motorik halus anak sebelum dan sesudah diberi kolase dapat dilihat melalui tabel dibawah ini, sebagai berikut:

Tabel 3 Peningkatan Skor PretestPosttest

\begin{tabular}{llccc}
\hline No & $\begin{array}{l}\text { Nama } \\
\text { Inisial }\end{array}$ & $\begin{array}{c}\text { Skor } \\
\text { Pretest }\end{array}$ & $\begin{array}{c}\text { Skor } \\
\text { Posttest }\end{array}$ & Peningkatan \\
\hline 1. & RPC & 27 & 57 & 30 \\
2. & DAS & 30 & 55 & 25 \\
3. & AK & 25 & 48 & 23 \\
4. & DF & 22 & 45 & 23 \\
5. & NP & 28 & 50 & 22 \\
6. & MGA & 35 & 52 & 17 \\
7. & NA & 29 & 47 & 18 \\
8. & APS & 32 & 54 & 22 \\
9. & FNS & 24 & 56 & 32 \\
10. & RA & 33 & 49 & 16 \\
\hline
\end{tabular}

Berdasarkan tabel diatas, perubahan yang signifikan ditunjukkan oleh FNS yang mendapatkan 32 poin setelah diberi perlakuan, maka anak tersebut kemampuan motorik kasarnya berada pada kategori tinggi. Namun pada beberapa anak apabila dilihat berdasarkan peningkatan poin berada pada kategori sedang, misalnya RA yang hanya 16 poin saja selisih antara pretest dan posttest peningkatannya. Hal tersebut dikarenakan faktor anak itu sendiri seperti yang diungkapkan oleh Hurlock (1987) bahwa anak yang memiliki kesempatan belajar termasuk dalam melakukan berbagai aktivitas yang berhubungan dengan kemampuan motorik kasarnya, maka kemampuannya pun akan berkembang lebih pesat daripada anak yang tidak memiliki kesempatan berpraktik sebelumnya. Berdasarkan data tersebut dapat dikatakan bahwa modifikasi permainan tradisional engklek memiliki pengaruh dalam meningkatkan motorik kasar dengan cukup signifikan. Melalui modifikasi permainan engklek perkembangan motorik kasar anak menjadi lebih baik terutama dalam 
menjaga keseimbangan dan berkoordinasi. Dalam modifikasi permainan tradisional engklek tidak hanya satu indikator saja atau seperti melompat saja yang berkembang, tetapi ada beberapa indikator lain juga seperti berdiri, berjongkok, dan kemampuan lainnya pun ikut berkembang.

\section{Pembahasan}

Permainan Tradisioanl merupakan salah satu permainan turun-temurun yang telah ada sejak dahulu berasal dari nenek moyang. Selanjutnya menurut Setyo (2009) permainan tradisional adalah permainan anak-anak dari bahan sederhana sesuai aspek budaya dalam kehidupan dilingkungan serta banyak mempunyai variasi yang dilakukan secara spontan. Kemudian, menurut Soepandi dalam Setyo (2009) permainan tradisional ini bisa dikatagorikan dalam tiga golongan, yaitu: permainan untuk bermain (rekreatif), permainan untuk bertanding (kompetitif) dan permainan yang bersifat edukatif. Permainan tradisional menurut Mulyani (2016) adalah suatu permainan warisan dari nenek moyang yang wajib dan perlu dilestarikan karena mengandung nilainilai kearifan lokal. Sejalan dengan pernyataan tersebut, Marzoan dan Hamidi (2017) menyimpulkan bahwa permainan tradisional merupakan kegiatan yang dilakukan dengan suka rela dan menimbulkan kesenangan bagi pelakunya, diatur oleh peraturan permainan yang dijalankan berdasar tradisi turun-temurun. Dapat disimpulkan bahwa permainan tradisional merupakan suatu permainan yang didapat dimainkan sendiri atau secara berkelompok yang merupakan peninggalan leluhur dan terus diwariskan secara turun-temurun. Pada dasarnya jenis permainan yang dilakukan oleh anak-anak sangat bervariasi dan dibedakan berdasarkan sifatnya, jenis kelamin, macam, bentuk serta saat kapan permainan itu dimainkan, di samping juga ditentukan oleh musim atau usumusuman. Artinya hanya pada saat-saat tertentu saja jenis permainan dimainkan oleh anak.

Permainan engklek atau permainan sonda sering dimainkan oleh anak laki-laki atau perempuan hal ini dapat melatih keseimbangan diri dengan melompat satu kaki, permainan engklek ini sering berjalannya waktu semakin ditinggalkan oleh penerus generasinya (Malichah, 2018). Permainan tradisional sangat erat kaitannya dengan kehidupan masyarakat dan merupakan bagian penting dari masa kanak-kanak di daerah pedesaan karena kemiskinan dan kondisi sederhana masyarakat yang tinggal di daerah tersebut mempengaruhi. (Sulistyaningtyas \& Fauziah, 2019). Permainan tradisional berperan dalam mengembangkan potensi anak perkembangan, seperti motorik kasar, halus, sosial, dan kognitif pembangunan, serta aspek pembangunan lainnya. (Rahmadani et.al., 2018). Menurut Montolalu (2005) permainan engklek adalah permainan tradisional asli Indonesia lompat-lompatan pada bidang datar yang digambar di atas tanah engan gambar berbentuk petak-petak, permainan ini dilakukan dengan melompat menggunakan satu kaki dari petak satu ke petak berikutnya.

Permainan tradisional engklek merupakan permainan yang sudah ada secara turun temurun, permainan ini dilakukan dengan berjalan atau melompat dengan satu kaki (Dharmamulya, 2008). Permainan Engklek adalah permainan yang memanfaatkan aktifitas fisik yaitu melompat dan berdiri dengan satu atau dua kaki pada kotak permainan yang telah digambar diatas tanah (Wiyono, 2015). Dapat disimpulkan bahwa permainan engklek merupakan permainan tradisional yang dilakukan dengn gerakan melompat-lompat 
menggunakan satu kaki dan melompat dilakukan di tanah ataupun di lantai dengan berbagai bentuk pola gambar. Dapat disimpulkan bahwa permainan engklek merupakan salah satu permainan tradisional turun-temurun asli Indonesia yang dilakukan pada media bidang datar atau di atas permukaan tanah dengan melakukan gerakan melompat ataupun berdiri dengan satu maupun dengan dua kaki, menjongkok serta dapat dilakukan dengan cara berjalan yang dimainkan secara individu atau berkelompok.

Dalam bermain engklek ada tahapan yang harus diikuti oleh pemain. Hal ini sesuai dengan pernyataan Mulyani (2013) dalam (Desvarosa, 2012) tahapan bermain engklek yaitu: (1). Menggambar pola engklek Permainan ini memang sebuah permainan outdoor atau permainan yang harus dilakukan di luar rumah. Permainan ini memerlukan sebuah pekarangan kecil yang datar dengan ukuran kurang lebih $3-4 \mathrm{~m} 2$, dapat dilakukan di atas tanah, ataupun di ubin. Lapangan atau arena sondah/engklek biasanya berupa kotakkotak atau persegi panjang dengan ukuran sekitar 30 - 60 m2 Untuk membuat lapangan, anak-anak biasanya menggunakan pecahan genteng atau batu. Jika dilantai dapat menggunakan kapur. Masing-masing anak mempunyai "gacuk" dari pecahan genteng atau keramik, yang bentuknya pipih agar tidak menggelinding. (2). Menentukan pemainan pertama, Semua pemain atau anak berkumpul lalu melakukan "hompimpah" Hompimpah alaihum gambreng, Hompimpah alaihum gambreng, ataupun "suit" untuk menetukan siapa yang bermain dahulu, karena cara bermainnya bergantian. Anak yang pertama kali menang mulain bermain. Dan (3). Melemparkan gacuk Pemain melempar gacuknya pada petak nomor satu. Gacuk yang dilempar harus berada didalam kotak, bila meleset ke kotak lain maka dinyatakan gugur dan diganti pemain kedua. Pemain pertama mulai melompat menggunakan satu kaki (kaki yang satunya diangkat, atau ditekuk kebelakang) dari kotak 1 hingga seterusnya kemudian berhenti sejenak, lalu kembali lagi dengan mengambil gacuk yang berada di kotak 1 dengan kaki satu tetap di angkat. Setelah itu pemain melemparkan gacuk ke kotak yang ke 2 jika keluar dari kotak kedua pemain dianggap gugur. Begitu seterusnya sampai semua kotak sudah dilempar dengan gacuk. Kemudian jika semua telah dilakukan oleh semua pemain maka pemain melemparkan gacuk dengan membelakangi engkleknya jika pas pada kotak yang dikehendaki maka kotak itu akan menjadi rumahnya jika pemain berhasil mengambil gacuknya pemain kembali ke kotak yang pertama dan menjadi pemenang.

Perkembangan

motorik merupakan perubahan yang terjadi secara progressif pada kontrol dan kemampuan untuk melakukan gerakan yang diperoleh melalui interaksi antara faktor kematangan (maturation) dan latihan atau pengalaman (experiences) selama kehidupan yang dapat dilihat melalui perubahan/pergerakan yang dilakukan. Senada dengan yang dipernyataan itu, menurut Hurlock (1987) perkembangan motorik adalah perkembangan pengendalian gerakan jasmani melalui kegiatan pusat saraf, urat saraf, dan otot yang terkoordinasi. Kemudian, menurut Santrock (2009) menyatakan bahwa keterampilan motorik kasar (gross motor skill) merupakan keterampilan yang melibatkan aktivitas otot besar seperti tangan seseorang untuk bergerak dan berjalan. Menurut Decaprio (2013) motorik kasar adalah gerakan tubuh yang menggunakan otot-otot besar atau sebagian besar otot yang ada dalam tubuh maupun seluruh anggota tubuh yang dipengaruhi oleh kematangan diri. 
Selanjutnya menurut Acroni (2012) motorik kasar adalah gerak fisik yang membutuhkan keseimbangan dan koordinasi antar anggota tubuh, dengan menggunakan otot-otot besar sebagian atau seluruh anggota tubuh. Misalnya seperti kegiatan berjalan, berlari, berlompat, merangkak dan mengayunkan tangan. Selain itu Zahraini (2016) menyebutkan keterampilan koordinasi motorik kasar mencakup ketahanan, kecepatan, kelenturan, ketangkasan, keseimbangan, dan kekuatan. Nurturing Early Learning (2013) (dalam Anggraini et.al., 2018) menyebutkan bahwa motor skills development includes three strands of learning, 1) Motor skills acquisition, 2) Health and fitness, 3) Safety awareness. Hal ini menjelaskan bahwa perkembangan motorik berkaitan dengan tiga pengembangan kegiatan yang meliputi penguasaan keterampilan motorik, kesehatan dan kebugaran, serta keselamatan. (Setiani, 2019). Dalam Permendikbud No.137 Tahun 2014 tentang Fisik-motorik sebagaimana dimaksud pada ayat (1), yaitu a). motorik kasar, mencakup kemampuan gerakan tubuh secara terkoordinasi, lentur, seimbang, lincah, lokomotor, nonlokomotor, dan mengikuti aturan; b). motorik halus, mencakup kemampuan dan kelenturan menggunakan jari dan alat untuk mengeksplorasi dan mengekspresikan diri dalam berbagai bentuk; dan c). kesehatan dan perilaku keselamatan, mencakup berat badan, tinggi badan, lingkar kepala sesuai usia serta kemampuan berperilaku hidup bersih, sehat, dan peduli terhadap keselamatannya. Menurut Hayati et.al., (2017) Gerak motorik kasar melibatkan aktivitas otot tangan, kaki, dan seluruh tubuh anak. Upaya membantu anak pada lingkup perkembangan motorik kasar,kegiatan pembelajaran hendaknya dilakukan melalui kegiatan bermain baik bermain indoor maupun outdoor (Devrizal et.al., 2019). Dapat disimpulkan bahwa perkembangan motorik kasar merupakan suatu kemampuan atau keterampilan yang melibatkan aktivitas gerak tubuh untuk melatih keseimbangan, kecepatan, kekuatan, dan koordinasi meliputi penggunaan otot-otot besar pada manusia.

\section{SIMPULAN}

Modifikasi permain tradisional engklek memiliki pengaruh terhadap perkembangan motorik halus anak, maka guru harus dapat mengembangkan perkembangan motorik kasar anak dengan membuat modifikasi permainan tradisional engklek menggunakan berbagai macam bahan ataupun media agar pembelajaran dapat lebih menarik dan menyenangkan bagi anak serta dapat mengembangkan kemampuan perkembangan motorik kasar nya. Dengan adanya penelitian ini diharapkan kepada para guru agar dapat mengembangkan perkembangan motorik kasar anak dengan memberikan pemahaman belajar kepada anak melalui belajar sambil bermain, bermain sambil belajar sehingga anak tidak merasa terbebani dengan kegiatan belajar yang membosankan. Penelitian ini dapat digunakan sebagai saran untuk meningkatkan kualitas siswa melalui modifikasi permainan tradisional engklek agar perkembangan motorik kasar anak dapat berkembang.

\section{REFERENSI}

Achroni, K. (2012). Mengomptimalkan Tumbuh Kembang Anak Melalui Permainan Tradisional. Yogyakarta: Javalitera.

Anggraini, M. A., Karyanto, Y., \& A.S, W. K. (2018). Pengaruh Permainan Tradisional Lompat Tali terhadap Perkembangan 
Motorik Kasar Anak Usia 5-6 Tahun. Journal of Early Childhood Care and Education, l(1), 18. https://doi.org/10.26555/jecce.vli 1.60

Askalin. (2013). 100 Permainan dan Perlombaan Rakyat. Yogyakarta: Nyo-nyo.

Decaprio, Ricahrd. (2013). Aplikasi Teori Pembelajaran Motorik di Sekolah. Yogyakarta: Divapress.

Devrizal, Rini, R., \& Fatmawati, N. (2019). Permainan Tradisional Meningkatkan Kemampuan Motorik Kasar Anak di PAUD Cahaya Kartini Bandar Lampung. Jurnal Pendidikan Anak, 5(2), 110.

Desvarosa, E. (2012). Penerapan Permainan Tradisional Engklek Dalam Meningkatkan Kemampuan Kognitif Anak Usia 5-6 Tahun Di Tk Bina Guna. Jurnal Handayani PGSD FIP UNIMED, 6(1), 109-116.

Dharmamulya, S. (2008). Permainan Tradisional Jawa. Yogyakarta: Kepel. Press.

Hayati, H. S., Myrnawati, C., \& Asmawi, M. (2017). Effect of traditional games, learning motivation and learning style on childhoods gross motor skills. International Journal of Education and Research, 5(7), 53-66.

Hurlock. E. B. (1987). Perkembangan Anak. Jakarta : Erlangga

Iswinarti. (2010). Nilai-Nilai Terapeutik Permainan Tradisional Engklek Untuk Anak Usia Sekolah Dasar. Naskah Publikasi Penelitian Dasar Keilmuan. Fakultas Psikologi: Universitas Muhammadiyah Malang: Malang.

Malichah, LNISR. (2018). Modifikasi Permainan Engklek Terhadap Kemampuan Mengenal Bentuk
Geometri Pada Anak Usia 5-6 Tahun. PAUD Teratai. 7(2): 1-9. Marzoan \& Hamidi. (2017). Permainan Tradisional Sebagai Kegiatan Ekstrakurikuler untuk Meningkatkan Kompetensi Sosial Siswa. Journal An-nafs. 2(1): 6282.

Montolalu, BEF. (2005). Bermain dan Permainan Anak. Jakarta: Universitas Terbuka.

Mulyani. (2016). Super Asyik Permainan Tradisional Anak Indonesia. Yogyakarta : Diva Press.

Munir, A. (2019). Pengaruh Permainan Balap Karung dan Egrang terhadap Peningkatan Kepercayaan Diri Anak Usia Dini di PAUD Cahaya Kecamatan Rambutan Kota Tebing Tinggi The. Jurnal Diversita, 5(2), 8694.

Rahmadani A, N. K., Latiana, L., \& AEN, R. A. (2018). The Influence of Traditional Games on The Development of Children's Basic Motor Skills. 169 (Icece 2017), 160-163.

https://doi.org/10.2991/icece17.2018.41

Santrock, JW. 2011. Masa Perkembangan Anak Edisi 11. Jakarta: Salemba Humanika.

Setiani, R. E. (2019). Pemanfaatan Permainan Tradisional Dalam Penanaman Nilai-Nilai Kebangsaan Di Tk Negeri Pembina 2 Purwokerto. AṣSibyān: Jurnal Pendidikan Anak Usia Dini, 4(1), 39-52. http://jurnal.uinbanten.ac.id/index .php/assibyan/article/view/1963

Setyo, A. (2009). Permainan Tradisional. Jakarta: Rineka Cipta.

Sumantri, MS. (2005). Pengembangan Keterampilan Motorik Anak Usia Dini. Jakarta: Dinas Pendidikan. 
Sulistyaningtyas, R. E., \& Fauziah, P. Y. (2019). The Implementation of Traditional Games for Early Childhood Education. 326 (Iccie 2018),

https://doi.org/10.2991/iccie-

18.2019 .75

Wiyono, ER. (2015). Studi Permainan Engklek Terhadap Kemampuan Motorik Kasar Anak Autis Di Sekolah Mutiara Hati Sidoarjo. Jurnal Kesehatan Olahraga, 03(1):105-109.

Zahraini, E. E. D. A. (2016). Upaya Meningkatkan Motorik Kasar Pada Anak Melalui Permainan Tradisional Balap Karung Estafet Pada Kelompok B1 PUD Supriyadi Semaarang Tahun AJARAN 2015/2016. 147(July 2015), 11-40. 